DOI: $10.2478 /$ rpp-2018-0003

PhD in Pedagogy, Associate Professor, NADIYA TYMKIV Ivano-Frankivsk National Technical University of Oil and Gas, Ukraine Address: 15 Karpatska St., Ivano-Frankivsk, 76018, Ukraine E-mail: nadia_tymkiv@ukr.net

\title{
CURRICULA AND PROGRAMMES IN PETROLEUM ENGINEERING FOR HIGHER TECHNICAL EDUCATION INSTITUTIONS: COMPARATIVE ANALYSIS
}

\begin{abstract}
The article states the analysis of the curriculum that regulates the main purposes, essence and directions for petroleum training. The importance and necessity of positive usage of Austrian, English and Norwegian experience at the time of petroleum engineers training in the petroleum industry has been stressed on. The structure and content of curricula in the process of the petroleum engineers training at the universities of pointed out countries have been analyzed. It has been designated that the terms "curriculum" and "programme" are connected with such outstanding British and American scholars as A. Bosanquet, D. Clark, S. Fraser, F. Hunkins, L. Lattuca, M. Linn, G. O’Neill, A. Ornstein, J. Stark et al. Based on their views it has been found out that these papers define the basic goals, meanings and essential rules for training. It has been outlined that an educational program plays a principal part in the organization of higher technical education, both as the way of interplay and as the foundation for judgment and student appraisal. Three beds of curriculum, e.g. national curriculum, internal, or municipal curriculum, university curriculum and annual plan are considered. All these are designed in an accessible, broad and collective methods, thus, educational program is more a series of actions to achieve results than a commodity. In essence, curriculum is a key paper and it considers the comprehension of humankind, community and training; it also combines the work of any university to regional and nationwide tactics. Moreover, lecturers develop their own provincial curricula established on their national certificates. Close attention has been paid to key contextual filters that influence the curriculum planning process. It has been emphasized that a curriculum is formed on future direction and competence-based pertaining to thought; it is integrated and condensed, it joins all fields of training and university activity. The article discloses special aspects of petroleum specialists' cycle education. The requirements of employers towards HEI graduates' competences are presented.

Keywords: curriculum, programme, course, professional education, academic plan, contextual context, professional competences, petroleum industry, labour market, foreign experience.
\end{abstract}

\section{INTRODUCTION}

The hydrocarbons industry has experienced profound modifications recently. Geopolitics is tremendously dynamic; environmental responsibilities are increasing; international request for crude oil and natural gas is expanding. Consequently, the industry is lack of competent specialists to a greater extent. But companies in the industry take training seriously; they comprehend the advantage of learning and do not require to be persuaded to prepare their workforce more and regularly review and update their work practices. 
In Europe, engineers have learnt to rate the special aspects of engineering when dealing with difficulties; still, the style in which they approach problem examining and determining vary up and down the countries. While significant dissimilarities have appeared and prevail within countries, it is likely, however, to pinpoint symbolic national designs that illustrate superior guidelines of advantage. For instance, in France engineering students learn that the apical worth is focused on mathematical bases from first standards in case if they find techniques of preventing or opposing its power, when in fact, in the United Kingdom students at all ranks are being disputed to identify the fundamental value of rational education in problem solving. At Fachochschulen in Germany, students systematically encounter the way that no characteristic work in engineering can appear without first acquiring a real sense of accuracy (Downey \& Lucena, 2004).

Engineering educators in Europe have explored to rectify engineering training by making it more understandable to students in order they can settle various engineering facets differently. European methods mostly have concentrated on accelerating the quantity of planning essence in the educational program, containing the presentation of design actions into more courses of study, more unlimited problem solving, and rising connections to certain sphere. On the whole, European series of actions have addressed to training alumni and alumnae for career ability to move by rearranging degrees, extending the technical meanings of engineering syllabi, and cultivating an organization of student exchanges among different countries (SEFI, 2002).

\section{THE AIM OF THE STUDY}

Our study is aimed at analyzing the curricula designed for training petroleum engineers in such countries as Austria, Great Britain, Norway, and defining their role in forming these experts' professional competency.

\section{THEORETICAL FRAMEWORK AND RESEARCH METHODS}

Theoretical and methodological facets of our study are based on works by such scholars as R. Diamond A. (1998) (a practical application and many templates in designing and assessing courses and curricula), T. Hewitt (2006) (implementing and managing the curriculum), P. Knight (2001) (a process approach to curriculum-making), L. Lattuca and J. Stark (2009) (the use of the concept of an "Academic Plan), J. Moon (2002) (module and programmes development), M. Neary (2003) (curriculum studies in post-obligatory and adult education), G. O'Neill (2015) (curriculum design in higher education), A. C. Ornstein and F. Hunkins (2009) (a substantial theoretical survey of curriculum theory and types), S. Toohey (2000) (aspects in planning courses for higher education) and others.

A lot of notable foreign scholars, namely, A. Alderson, A. Blackwell, A. Butorac, S. Billett, S. Echaore-McDavid, J. Figgis, A. Lidgett, R. McDavid, K. Mitchell, A. Standen, A. Zubrick and others have paid considerable attention to petroleum engineers' professional training, skill development in the hydrocarbons industry and shed some light on the intricate and nearly sophisticated occurrence that there are some knowledge that cannot be instilled, but that can be mastered. Their work clearly shows that a curriculum angles for the equilibrium between learning accomplishment and student progress and it contributes typical way to the methods and prospering of training and learning.

To reach the goal of the study we have used such methods as theoretical analysis, synthesis, systematization, generalization, comparative analysis.

\section{RESULTS}

The term "programme" is typically used to explain an achieved set of academic units that greatly influences a qualification or reward. Moreover, this can also be outlined, 
in some framework, as the "course". According to G. O'Neill (2015), to accumulate the disorientation, "course" can also be needed where "module" is practiced in the modular system, as a "unit" of credit-bearing learning that is an element of a programme. The term "programme" and "curriculum" are also applied in junction, where curriculum often considers a broader conceptual system and framework. S. Fraser and A. Bosanquet take the view that staff working in higher education understand in their own ways the term "curriculum: the form and meaning of a subject; the form and essence of a syllabus; the students' background of studying; an active and mutual method of training and learning (Fraser \& Bosanquet, 2006).

L. Lattuca and J. Stark drew attention to that fact that personnel worked with identical disintegration of this notion. Therefore, they supported a practical context for all curriculum collaborators is the operation of the idea of an "Academic Plan", which stresses on the planning means, and comprises eight essential features: 1) aims, 2) content, 3) order, 4) learners, 5) pedagogical processes, 6) didactic resources, 7) assessment, 8) adjustment. The scholars outlined that the scheme is made in the social and cultural framework (Lattuca \& Stark, 2009).

This conception of developing sets of actions is emphasized in the regularly used notion "curriculum design" and is "mainly accepted as an important system explaining the learning to appear within a definite educational program, pointing to particular units of credit or accomplishment" (JISC, 2014). Curriculum scheme has frequently been interpreted in junction with the definition "curriculum development". A. Ornstein and F. Hunkins (2009) claim that curriculum development comprises a curriculum planning, implementation, and evaluation.

When analyzing foreign technical education, it needs to be pointed out that curriculum improvement initiatives are developing more global in Europe with many higher educational institutions investigating to connect learning superiority with a bigger stress on, particularly, abilities such as critical thinking and productive exchanging information and ideas, causing acceptance to more automatic training and personal growth, and educating students for worldwide citizenship. Clearly, curriculum improvement and a more unified structure to learning do not essentially comprise "interdisciplinarity" and the instructional techniques involved in some explanations of training supplying are not exclusive to interdisciplinarity (Lyall, Meagher, Bandola \& Kettle, 2015).

Austria has a number of great higher educational establishments proposing oil and gas-linked degrees courses such as engineering and geology. Due to to its superb regulation of training and close collaboration with the petroleum sector, Montanuniversität Leoben has advanced into a globally recognised centre of training for petroleum specialists. Both bachelor's or master's programmes in oil and gas engineering courses are conducted in English; the bachelor's programme takes seven semesters, while master's programme continues during three semesters.

Promising petroleum experts should not only take pleasure and be concerned in technology and the natural sciences, be desirous about languages and overseas practices. According to preferred specialty, future petroleum professionals have to cope with stress and be responsible, operate within a team or propose reasonable idea actions and leadership competences. The Bachelors program considers all appropriate fields concerning oil and natural gas technology: seeking petroleum and natural gas (geosciences), surveying and modelling reservoirs (reservoir engineering), eradication with drills (drilling engineering) and the development and depository of fossil fuels (production engineering). The Masters 
programme "International Study Program in Petroleum Engineering" delivers future petroleum engineers the chance to specialize in one of these key industrial sectors.

Global Study Program in Petroleum Engineering (the master's programme) goals at cultivating skills and additional enriching scientific competences in the area of oil and gas engineering, identical to the regulations of Masters programmes at British and American higher educational institutions. Learners can take one of the next three fields: Drilling Engineering: motionless and active sketches of well-bore structures, the directions of drilling actions, planning, verifying and appraisal of drilling projects; Petroleum Production Engineering: preparation, layout and support of production systems and natural gas depository conveniences, techniques for enlarging the activity of petroleum wells, the usage of geothermal energy; Reservoir Engineering: monitoring the quality of geological simulation of reservoirs, execute ground investigations (Hole, 2017).

Future petroleum experts have the chance to acquire an understanding into their future jobs during their necessary useful field work. Alumni and alumnae are trained for their recruitment on drilling rigs and production sites, and as planning engineers in drilling, reservoir and production engineering as well as in the field of pipeline and plant engineering. They are ready to hold administration positions at all ranks. Montanuniversität has turned into a globally praised preparing centre for petroleum specialists. Lectures for the Petroleum Engineering Masters programme are delivered in English. The worldwide prominence of the program is more increased by a diversity of exchange programs.

Education, obtained in Britain, has the reputation of one of the best in the world. It is considered that the quality of British education rests on "three pillars": excellent equipment of educational institutions, innovative educational technologies and cancellation of passive training system in favour of active individual work.

The University Heriot-Watt (HWU), the first technical college of the UK, was established in 1966. HWU has gained much popularity due to its school in training petroleum engineers. In 2002 the Department of Petroleum Engineering received the status of Institute. The graduates of the Institute of Petroleum Engineering HWU successfully work in many major oil companies far beyond the UK. HWU advances in the field of oil engineering are greatly appreciated around the world. HWU is actively working at international projects and cooperates with foreign universities.

The course "Oil engineering" is taught to future petroleum professionals during 12 months. This course consists of four semesters. During the first two semesters (from October to March) future petroleum experts get basic training in geology, geophysics, development, modeling, drilling, oil production and economics. As a rule, lectures are delivered by HWU Professors; classes are performed under the supervision of tutors. During the third semester (from April to June) students combined in groups prepare their projects of real oil fields development on the territory of the United Kingdom. During the fourth semester they work in oil companies and carry out individual research projects. Such specialists are the team of world-class in petroleum engineering, geology of oil and gas fields, construction of surface field facilities, and at present they are unique and have the potential to be popular in the future.

Robert Gordon University is situated in Aberdeen, "oil capital" of the UK, in the ancient town, where there are offices of more than 400 foreign companies, most of which operate in the field of oil and gas industry: Shell, BP and Total. Thus, 96 per cent of graduates are employed or continuing their postgraduate education within 6 months (after graduation), 90 per cent of courses offer students internships. A number of master's degree 
programs are proposed for future oilmen in economic direction as oil, for instance, MBA in petroleum field MSc in Oil and Gas/Petroleum Engineering or Master of Science in oil development. There are also annual programs for certified accountants and lawyers who work in the petroleum area: accounting in the petroleum sector and oil and gas and legislation.

The Department of Engineering at Aberdeen University is a general or integrated department which covers the main branches of engineering. Engineering degrees at Aberdeen are broadly based and do not require students to make an early commitment to a single discipline. Students taking the BEng and BscEng can gain an insight into the range of engineering disciplines in addition to developing a specialism, and this makes Aberdeen unique among Scottish Universities. It assists engineers in their professional careers to have a broad understanding especially in their capacity as managers. The amount of diversity in technology is very quick, joined departments which stress the united essence of engineering are being increasingly recognised as the most appropriate basis for the teaching of engineering. The Level 1 and 2 courses for BEng and BscEng students cover all branches of engineering and at Level 3 or 4 students may develop a specialisation or continue with a general or integrated programme. The principle aim of the undergraduate teaching is to educate students to a high standard in the fundamentals of engineering including, in particular, the principles and role of design and an appreciation of engineering practice and of the importance of economic, financial, safety, managerial and social factors. Additional goals involve the growth of communicative abilities, support creative and free thinking and consolidated training.

An innovative feature of the Department has been the introduction of courses in the third and fourth years in the relatively new subject of safety and reliability engineering. These courses may be taken by all engineering students. All courses in the University are fully modularised, which enhances their flexibility. In Engineering, students' choices are kept open by having the first two years of the four-year degree taught in common, so that decisions about which branch of engineering to specialize in can be made at a point when a student has some experience of engineering to help in making an informed decision. Petroleum engineering programs operate with the help of lectures, group tutorials and seminars, exclusive meetings between learners and personnel. The number of lectures differs greatly - from a few to 300 or more - but in all departments small-group training supports the lectures and in most departments it progressively moves lectures as the Honours programme advances. Evaluation comprises both regular assessment and recorded examination papers. Examination dates pursue each half-session of training. Designated degrees are achieved by accumulating the correct number of credits, including a proportion in the subject in which the designation is given; they are also unclassified. Honours degrees work similarly but at the end are classified as First, Second (Upper or Lower) or Third class.

The University of Stavanger (UiS) is considered to be one of the best places to study petroleum engineering in Norway, located in the undisputed oil capital, Stavanger. UiS is renowned for its close contact with the oil and gas industry, with the headquarters of 26 international oil and gas companies in the region. It offers English Master's programmes in a wide range of courses, including Offshore Technology, Environmental Technology, Petroleum Engineering, and Petroleum Geosciences Engineering. It was recently chosen by the Norwegian Government to host Norway's new cutting-edge petroleum research centre for Improved Oil Recovery, based on a national competition evaluating scientific quality and collaboration with industry. The degree in Petroleum Engineering has been offered since 1977 and is at the prominence of oil and gas engineering training all over the world. It offers three specializations; Well Engineering, Reservoir Engineering and Natural Gas 
Engineering. The degree in Offshore Technology is stressed on technical resource management, risk management and problems connected to the construction of offshore establishment for the petroleum industry. This program combines three trends of specialization; Industrial Asset Management, Marine and Subsea Technology and Risk Management. The degrees have a global description and supplies both Norwegian and foreign learners.

Also, UiS has capable exploration groups in the offshore technology field. Within petroleum engineering, investigation fields contain drilling, natural gas, asset and decision determination, petroleum geosciences, construction and reservoir. Offshore technology analysis involves standards, hypotheses and techniques for preparation, growth, administration and disassembling technological systems and supplies, especially concentrated on offshore fittings.

No matter when petroleum engineers obtained their degree and or how many years they have been working in the petroleum industry, there are always new things to learn. True with any profession, it's essential to stay current on industry trends, to remain knowledgeable about new standards in any industry, and to learn about advances that have either been implemented or are on the horizon. Many engineers who work in the petroleum industry have been dedicated to their profession for many years. It can be difficult to keep up to date on industry changes and transitions without enrolling in a continuing education course, petroleum education certificate program or petroleum education workshop. Continuing education ensures that engineer expertise will be in line with others in the petroleum industry.

\section{CONCLUSIONS}

Overall, in most European universities all facets of an excellent curriculum and programme are in quantity: experienced academic personnel, superb laboratory conveniences, a big consolidation with industry and a profound supply of possible students who are ready for an engineering learning. It is evident an equilibrium between the theory and practice in the design of higher education program. The language of curriculum outline can be puzzling and concern is demanded when working in various framework and collaborators. Comparing the structure of petroleum engineers professional training in Austria, Great Britain and Norway it has been revealed conceptually that at the current stage in above-mentioned countries professional training is carried out in the terms of stepwise education on the basis of competence, practice-oriented and learner-centered approaches, principles of humanization, the combination of national traditions with trends in international educational space directed to the development of a fundamentally new type of highly competitive expert in the petroleum industry.

The perspectives for further studies are the training students of Petroleum Engineering for interdisciplinary teamwork.

\section{REFERENCES}

1. Diamond, R. M. (1998). Designing and assessing courses and curricula: a practical guide. San Fransisco: Jossey-Bass.

2. Downey, G. L., \& Lucena, J. C. (2004). Knowledge and professional identity in engineering: code-switching and the metrics of progress. History and technology, 20 (4), $393-420$.

3. Figgis, J., \& Standen, A. (2005). Training for skilled workers: lessons from oil and gas industry. Adelaide, Australia: NCVER. 
4. Hewitt, T. W. (2006). Implementing and managing the curriculum. In T. Hewitt (Ed.), Understanding and shaping curriculum: what we teach and why? (pp. 287-313). London: Sage Publications.

5. Hole, M. (2017). Petroleum geology. Retrieved from www.abdn.ac.uk/study/ undergraduate/degree-programmes/680/F602/geology-and-petroleum-geology/.

6. JISC. (2014). Enhancing curriculum design with technology, outcomes from the JISC institutional approaches to curriculum design programme. Retrieved from http://www.jisc.ac.uk/sites/default/files/enhancing-curriculum-design.pdf.

7. Knight, P. T. (2001). Complexity and curriculum: a process approach to curriculum-making. Teaching in higher education, 6 (3), 369-381.

8. Lattuca, L. R., \& Stark, J. S. (2009). Shaping the college curriculum: academic plans in context. (2nd ed.). San Francisco, CA: Jossey-Bass Inc.

9. Lyall, C., Meagher, L., Bandola, J., \& Kettle, A. (2015). Interdisciplinary provision in higher education: current context and future challenges. Retrieved from https://www.heacademy. ac.uk/system/files/interdisciplinary_provision_in_he.pdf.

Kindle Edition.

10. Lidgett, A. (2016). Petroleum: common commodities and industries. London:

11. McDavid, R. A., \& Echaore-McDavid, S. (2006). Career opportunities in engineering. New York, NY: Ferguson.

12. Moon, J. (2002). The module and programmes development handbook. London: Kogan Page.

13. Neary, M. (2003). Curriculum studies in post-compulsory and adult education: a teacher's and student teacher's study guide. Cheltenham: Nelson Thornes Ltd.

14. O'Neill, G. (2015). Curriculum design in higher education: theory to practice. Retrieved from http://www.ucd.ie/t4cms/UCDTLP0068.pdf.

15. Ornstein, A. C., \& Hunkins, F. P. (2009). Curriculum foundations, principles and issues. (5th et.). Boston, MA: Pearson Education Inc.

16. SEFI. (2002). The Bologna Declaration and engineering education - a discussion paper. Brussels: European Society for Engineering Education.

17. Toohey, S. (2000). Designing courses for higher education. Buckingham: SRHE \& Open University Press. 